\title{
THE DRIFT TOWARD A CONSUMER CREDIT CODE*
}

\author{
F. B. HUBACEER $\dagger$
}

$\mathrm{I}^{\mathrm{N}}$ N THE December I944 issue of this Review, Professor George G. Bogert presented a valuable article on the future of small loan legislation. I During the ensuing years the trends of legislation in that field have been in the direction he advocated, although progress has been slow and erratic. The subject in both its legal and economic aspects is now in just as dynamic a phase as it has been since late in the nineteenth century. Another treatment of the subject may not now be premature.

This paper will attempt to bring Professor Bogert's article up to date, to point out some of the influences which have been at work, to suggest future developments, and to supplement certain of Professor Bogert's conclusions. His scholarly discussion was a landmark in a field which has been little understood and much misunderstood. Ancient prejudices, preconceived but unfounded beliefs, and the pleadings of special interests have often obscured the real elements of the problem and distorted the true nature of the public interest. In his matter-of-fact way, Professor Bogert made clear the desirability of a rational, factual, systematic approach to a code of regulatory laws dealing with the modern socio-economic problems of consumer installment credit.

As this paper will start where he stopped, it seems necessary to set forth a summation of his foundation article. Professor Bogert noted that "[i]n the last quarter of the nineteenth century there arose sporadically an appreciation of the woeful condition of the small borrower and of the need for special legal attention to his relief." Conventional usury laws fixed maximum percentage interest rates of universal application, failing to recognize that a rate which made a large loan profitable would produce a

* This article was written during March 1949 , and speaks as of December 3I, I948 unless otherwise indicated. The sentence to which note 60 , infra, is appended was added on June 15 , I949. A summary of consumer credit legislation from January to June I949 appears in the Bulletin of the Law Forum of the National Consumer Finance Association, Washington, D.C.

$\dagger$ Member of the Illinois Bar. General Counsel, Household Finance Corporation. Alternate of Price Administrator under Presidential Order in drafting and administration of Regulation W, 194I-43. For many years Chairman, Law Committee, American Association of Personal Finance Companies. Now Chairman, Committee on Law Bulletin, Law Forum of National Consumer Finance Association.

× Bogert, The Future of Small Loan Legislation, I2 Univ. Chi. L. Rev. I (r944). 
dollar amount on a small loan which was less than the lender's costs. Usury laws were not enforced because that required legal action by an individual borrower, and the overcharge for a small loan was usually less than the costs of the necessary litigation. The growing demand for individual credit in small amounts was supplied at high and usurious rates under oppressive conditions. Legislatures, convinced that borrowers were characterized by need, economic weakness, and lack of adequate legal remedies, began by attacking isolated features such as wage assignments and chattel mortgages, then turned to regulation of and grants of special powers to classes of lenders. ${ }^{2}$

Professor Bogert referred to the resulting legislation either as "miscellaneous, casual, and unsystematic reform measures attempting to improve the condition of the small borrower," or as "systematically prepared statutes, each of which relates to one type of lending agency only." The result was a "hodgepodge of inconsistent rules and controls, favoring some lenders and borrowers." Professor Bogert asked four basic questions and developed the following reasoned conclusions: r) The states should regulate the small loan business. 2) Regulation should include fixing maximum rates of charge. 3) A uniform method of stating the rate of charge should be applied to all lending agencies, though the maximum rates may differ. 4) An over-all percentage rate of charge computed as simple interest on the unpaid principal balances of a loan is the best form of rate statement.

In Professor Bogert's article, it was implicit that, as the result of an expanding demand for consumer credit and the entry of new types of creditors into the business, small loans had become only part of a larger

2 For detailed and comprehensive discussions of the problem and corrective steps, see Gallert, Hilborn, and May, Small Loan Legislation, esp. cc. i-iv, vi (Russell Sage Foundation, I932); Robinson and Nugent, Regulation of the Small Loan Business, esp. cc. i, iii (70-73), iv, $v$ (Russell Sage Foundation, I935); Wassam, The Salary Loan Business in New York City (Russell Sage Foundation, Ig08); Ham, The Chattel Loan Business (Russell Sage Foundation, I909); Ryan, Usury and Usury Laws I27 et seq. (I924); Provident Loan Society of N.Y. v. Chambers, 88 N.Y.S. 2d 459 (1949), N.Y. L.J., p. 995, col. 5 (March I8, I949).

The plight of the small borrower under the usury laws and the necessity for remedial legislation are shown by numerous decisions, including the following:MadisonPersonal Loan, Inc.v. Parker, I 24 F. 2d 143 (C.C.A. 2d, I94I); In re Home Discount Co., I47 Fed. 538 (D.C. Ala., r906); State ex rel. Smith v. McMahon, I28 Kan. 772, 280 Pac. 906 (I929); Davis Loan Co. v. Blanchard, $I_{4}$ La. App. 67r, I29 So. 4I3 (1930), rehearing den. I30 So. 472 (I930); Liberty Finance Co. v. Catterton, I6x Md. 650, I58 Atl. I6 (1932); State ex rel. Goff v. O'Neil, 205 Minn. 366, 286 N.W. 316 (I939); State ex rel. v. Family Loan Co., r67 Tenn. 654, 73 S.W. 2d I67 (1934); Cotton v. Cooper, 209 S.W. 135 (Tex. Com. App., I9I9), aff'g I60 S.W. 597 (Tex. Civ. App., rgr3). See Simpson, Cost of Loans to Borrowers under Unregulated Lending, 8 Law \& Contemp. Prob. 73 (194r); Birkhead, Collection Tactics of Illegal Lenders, 8 Law \& Contemp. Prob. 78 (I94I). For other references, see Barrett and Ulrich, Index to Legal Literature on Regulation of Consumer Installment Lending and on Usury Laws (Law Forum of National Consumer Finance Association, I948). 
problem. ${ }^{3}$ There are now several types of agencies which extend credit to the consumer by different methods. Knowledge of the relative importance of these agencies will assist in understanding the issues to be considered in this article (Table I).

TABLE 1

\section{Consumer INSTALLMENT CREDIT4}

(December 3r, I948)

\begin{tabular}{|c|c|c|}
\hline \\
\hline \multirow{2}{*}{\multicolumn{3}{|c|}{ Sales financing: }} \\
\hline & & \\
\hline Incidental to automobile transactions........ & $\$ \mathrm{I}, 96 \mathrm{I}$ & \\
\hline Incidental to sale of other goods. & $2, I 34$ & $\$ 4,095$ \\
\hline \multicolumn{3}{|l|}{ Installment loan credit: } \\
\hline 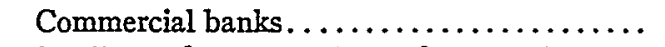 & $\$ 1,709$ & \\
\hline Small loan [consumer finance] companies..... & $8 \mathrm{I7}$ & \\
\hline Industrial banks and loan companies.... & 364 & \\
\hline 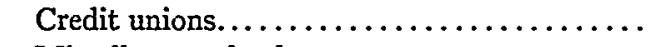 & 312 & \\
\hline Miscellaneous lenders. . . . . . . . . . . . & I3I & 3,333 \\
\hline FHA repair and modernization paper......... & & \\
\hline To & & $I$ \\
\hline
\end{tabular}

It will be seen from Table $I$ that the four principal types of installment credit agencies ${ }^{5}$ are consumer finance (small loan) companies, industrial

3 For recognition of interrelationship of all forms of consumer finance, see Report of Indiana Department of Financial Institutions on Indiana Consumer Finance Agencies (I935); Schmus, The Banker's View, 33 Consumer Finance News 6 (Nov. 1948); Section I of Proposed Bill under Consideration by New York State Joint Legislative Committee on Installment Financing, introduced with amendments in the 1949 Legislature as S.B. No. 820, and Interim Report of the Joint Legislative Committee on Installment Financing (March 2, 1948); Mors, Rate Regulation in the Field of Consumer Credit, 16 J. of Bus. of Univ. Chi. 5I, I24 (I943). For entry of banks into the consumer finance field, see Baird, Commercial Bank Activity in Consumer Instalment Financing, 33 Fed. Reserve Bull. 264 (March I947); Mors, Commercial Banks and Competitive Trends in Consumer Installment Financing, $21 \mathrm{~J}$. of Bus. of Univ. Chi. I33 (1948); Paddi, The Personal Loan Department of a Large Commercial Bank, rg6 Annals I35 (r938).

${ }^{4} 35$ Fed. Reserve Bull. 300 (March 1949). In classifying consumer installment credit according to types of lenders, the Federal Reserve Board uses the term "small loan companies." The term "consumer finance companies" or "regulated consumer finance companies" is often used to mean the same thing.

A substantial part of the figures for loan credit extended by commercial and industrial banks, is in fact sales finance credit. For comments re the effect of FRB classification procedure, see Dauer, The Place of Consumer Finance Companies in the Consumer Credit Field, 33 Consumer Finance News 4, 5 (Nov. 1948). For other comments on the Federal Reserve statistics, see Dauer, Consumer Credit, the Long View and the Short View, 37 Credit World 4, 6 (March 1949), 3o Great Lakes Banker I4, 24 (March 1949).

5 The following agencies will not be considered herein: pawnbrokers and remedial or semiphilanthropic loan associations, which are included under "Miscellaneous lenders" above, and credit unions.

Economically, the pawnbroker is on the periphery of the field. The ancient pawn transac- 
loan companies, ${ }^{6}$ banks, and sales finance companies. Sales financing now accounts for over half of total consumer installment credit. Most if not all of Professor Bogert's conclusions apply with equal force to consumer installment debt arising from the sale of goods and to the creditors in such transactions. The inequality in the bargaining power of the debtors is approximately the same. The urge to acquire goods approaches in impelling power the need for money. The lack of financial sophistication of buyer and borrower, their need for advance disclosures in order to make intelligent decisions, and the inadequacy of their legal remedies are much the same. ${ }^{7}$ Possibly of equal importance is the fact that the different types of credit are often equally available at the option of the consumer. The car buyer at the teller's window gets a blue note if he wishes to borrow the purchase price and mortgage the automobile, or a white contract if he decides to buy it on a conditional sale plan. The consumer with $\$ 50$ in his pocket can use it to pay the doctor and then borrow to buy something, or he can use it to make a down payment and borrow to pay the doctor. It is important to note, however, that installment sales in larger amounts, such as for an automobile, do not involve the same impelling necessity as money for the doctor, and the social consequences of overreaching in the automobile transaction may not be as serious.

Professor Bogert, it is submitted, saw the need not for a small loan

tion is not a loan. There is no debt, the res alone being responsible for the amount at stake. Provident Loan Society of N.Y. v. Chambers, 88 N.Y.S. 2d 459 (I949), N.Y. L.J. p. 995, col. 5 (March I8, r949). In modern times, largely because of statutes, the term "pawnbroker" is sometimes corrupted and applied to pledge loans. Mottershead, Pawn Shops, I96 Annals I49 (I938).

The remedial loan association, while very important socially, has become a static element and quantitatively is a minor factor. Ibid.

The credit union is also a comparatively static institution. Socially, it is of great importance and usually a benefit. Economically, it is the smallest of the consumer credit classes statistically recognized by the Federal Reserve Board. In passing, it should be noted that the Federal Credit Union Act poses an open jurisdictional question of federal versus state regulation of consumer credit. This act purports to grant a greater or different interest privilege to its creatures within many states than is possessed under the state's law by its own citizens or residents. The fixing of interest maxima has always been considered a state police power function. If the federal usurpation is sustained, there is no other basis than the absurd ipsi dixit that credit unions created under the act are fiscal agents of the federal government.

"The term "consumer finance companies" is now more often used than the term "small loan companies." The term "industrial loan companies" as used in this article includes industrial banks, Morris-Plan banks or companies, and discount companies. These terms are often used almost synonymously.

${ }^{7}$ Section I of Proposed Bill under Consideration by New York State Joint Legislative Committee on Installment Financing, introduced with amendments in the I949 Legislature as S.B. No. 820, and Interim Report of the Joint Legislative Committee on Installment Financing (March 2, I948); Pa. Motor Vehicle Sales Finance Act § 2, Pa. Stat. Ann. (Purdon, Supp. I948) tit. 69, § 602; Summary Report of the Joint State Government Commission to the General Assembly of Pennsylvania, pp. I4-20 (March 2I, I947). Compare Clark, Financing the Consumer 227, 235 (1933). 
code but for a consumer installment credit code. His thesis called for comprehensive legislation to unify or at least harmonize the regulations within an area of our national life which comprises a social and economic unit.

It should be borne in mind that there is a vital difference between consumer credit extended on installments and all other types of consumer credit. The Federal Reserve Board classifies all consumer credit as installment credit, single payment loans, charge accounts, and service credit. ${ }^{8}$ Despite their volume and the great difficulty of classifying single payment loans, charge accounts, and service credit, these types of credit ordinarily do not involve the possibilities of deception and overreaching which are inherent in installment credit. Charges for these credits usually are not high, the bargaining power of the customer is stronger, and the social consequences of overreaching are less disastrous than in the case of installment credits. Nevertheless, the ease with which a consumer installment debt can be disguised as a single payment loan or a charge account will create grave problems in the application of a comprehensive code to consumer installment credit. The impotence of Regulation $\mathrm{W}$ in respect to single payment loans illustrates the difficulties to be met.

Whether or not a consumer's debt is repayable in installments is a characteristic upon which the most basic distinctions rest. An installment debt is geared directly to the average consumer's manner of life. It reflects the wage system. The consumer receives his income in periodic increments and his normal expenses are payable in the same manner. The consumer may be confronted with two kinds of financial problems: one is the gradual accumulation of small debts which finally become unmanageable except by a refunding operation; the other is a sudden need for a sum beyond the savings which he has or is willing to use. Whether he gets into debt slowly or suddenly, he can only get out of it gradually. The most typical consumer debt, the obligation which society can feel sure is truly a consumer's obligation, is one repayable in installments.

The installment feature is also very important from the viewpoint of regulation because it lends itself so readily to deception and overreaching, both in soliciting the consumer to become indebted and after he has become a debtor. A principal reason is the readiness with which the average person mistakenly identifies a rate of discount with a rate of interest. In an installment debt the amount of principal of which the debtor has the benefit declines with each payment. A loan of \$120, if repaid at \$1o a

${ }^{8} 35$ Fed. Reserve Bull. 300 (March I949). Out of approximately I6 billion dollars of total consumer credit outstanding on December $3 \mathrm{I}$, I948, the Board assigns $\$ 2,902, \infty 00,000$ to single payment loans, $\$ 3,854, \infty \infty, \infty \infty$ to charge accounts, and $\$ 972,000,000$ to service credit. That leaves $\$ 8,196, \infty 00,0 \infty 0$, or approximately one-half of the total, to consumer installment credit. 
month, approximates $\$ 60$ of principal debt for one year or $\$ 120$ for 6 months. Six per cent of $\$ 20$ discounted, that is subtracted at the beginning of the transaction, is equivalent to between II per cent and I2 per cent per annum interest. Out of this molehill has grown a mountain of difficulty in regulating consumer installment credit. ${ }^{9}$

The complexities of interest rates in installment credit, combined with the economic weakness of the debtor, necessitate legislation to protect the debtor from deception and oppression. ${ }^{x 0}$ The most important respects in which unfairness to the debtor can occur are, first, in the representations and disclosures made to consumers who contemplate going into debt, then, in the charge exacted for the credit extended, and, finally, in the remedies available to the creditor for collection. Of these three, the rate of charge is the crux.

In view of recent wartime experience, it seems unnecessary to dwell on the variety of subterfuges which can be used to defeat price control. The problem of enforcing price control in the loan field approximates that in other fields. Everyone is familiar with the tie-in sale, the sub-rosa payment to the janitor, or the purchase of furniture to get an apartment, the deterioration in quality, and the reduction in service which can come with price control. The problem in the consumer installment credit field has been to control the price, to prevent evasions, and at the same time keep high standards of service and foster competition. The rate authorized to be charged must be high enough to permit competitive rate reductions and to encourage improved service. Below that point destructive consequences are inevitable. ${ }^{\mathrm{Ir}}$

9 See notes 29,30 infra.

ro Bogert, op. cit. supra note $x$. See also note 2 supra. "The unregulated small loan business has in fact produced a chain of evil consequences. Of this, experience has furnished conclusive demonstration. Borrowers have almost invariably been poor people at times of their most exigent needs. Untrained in the refinements of business negotiations, usually ignorant of the existence of usury laws, and incapable of using the rights which the law gave them, they have often fallen easy victims of unconscionable money lenders. The lenders, on the other hand, have generally been persons endowed with a shrewd business sense for profitable opportunities, and in many cases have been more devoid of respect for usury statutes than the more responsible lenders of larger sums. Frequently this has been due not so much to the inordinate greed of lenders, as to the fact that the usury laws assumed risk and expense factors in lending much below those in the small loan business. Whatever its cause, the result has been to subject a considerable body of the public to oppressive and illegal interest exactions. The sufferers have been the economically weak. The conditions under which lender and borrower met lacked that equality of bargaining power essential to just business transactions. That the state has a right to prevent the stronger from pressing his advantage to the point where it entails injurious social results has been recognized by the courts. . . " F. R. Hubachek (the author's father), The Constitutionality of Small Loan Legislation (I93I), reprinted in Gallert, Hilborn, and May, op. cit. supra note 2, at I32.

Ir Sixth Draft of Uniform Small Loan Law, n. r4; Robinson and Nugent, op. cit. supra note 2 , at $285-88$. 
The paramount problem of rate control in consumer installment credit is made more difficult by the devices of the usurer to increase and obscure the real rate of charge. The subterfuges of the usurer are almost infinite but they fall into five classes: ${ }^{2}$

I) Concealment of the fact that the transaction is a loan. In this class fall pretended purchases of property at low prices or sales at high prices, and casting the transaction in the form of a "hazard" agreement.13

2) Use of a collateral transaction such as the sale of something to the borrower on which the lender makes a profit, or the use of a third person who exacts something from the borrower for the lender's benefit. ${ }^{24}$

3) Exaction of charges ostensibly for something other than the use of money. Typical examples are "service charges," "fees," "loss reserves," "fines," and "collection expense." 15

4) In the case of installment loans, discounting the maximum rate of interest permitted by the general usury law with the interest computed on the original amount of the loan for the full period of the contract without regard to the declining principal balances. ${ }^{16}$ This device is often accompanied by refusal to refund unearned charges when the loan is refinanced before maturity.

5) Outright fraud, such as filling out blanks falsely, taking two notes, arbitrarily increasing the principal amount or the length of time involved, or failing to credit payments properly, making inaccurate computations, and charging arbitrary fines for defaults..$^{77}$

Statutory regulation in this field will not be effective unless the devices by which the debtor is overreached and oppressed are prevented, in fact not in theory, without curtailing the extensions of installment credit which the consumer demands. In framing such regulation, fortunately, the benefits of over forty years of experience are available through the large scale research and experimentation conducted by the Russell Sage Foundation.

This started shortly after the turn of the century. With the mechaniza-

${ }_{22}$ Hubachek, Annotations on Small Loan Laws, Pt. III (Russell Sage Foundation, 1938), which lists four of the five classes and discusses discounting under the heading "Confusion in Computation" rather than as a separate class of device; Detection of Usurious Claims and Illegal Charges in Wage Earner Bankruptcies, Pt. III (Conference on Personal Finance Law, I943); Scott v. Lloyd, 34 U.S. (9 Pet.) 418 (1835).

${ }^{13}$ Missouri, Kansas \& Texas Trust Co. v. Krumseig, x72 U.S. 351 (1899); People v. Vanderpool, II4 P. 2d 608 (Cal. App., I94I), rev'd on other grounds 20 Cal. 2d 746, I28 P. 2d 513 (1942); State on Inf. of Taylor v. Salary Purchasing Co., 218 S.W. 2d 57 I (Mo. S. Ct., x949).

14 Fowler v. Equitable Trust Co., I4I U.S. 384 (I89r); Jernigan v. Loid Rainwater Co., I96 Ark. 25r, II7 S.W. 2d I8 (r938); Searl v. Earll, 62 A. 2d 374 (Mun. C.A. D.C., I948); Commonwealth ex rel. Grauman v. Continental Co., 275 Ky. 238, I2r S.W. $2 d 49$ (r938).

${ }_{25}$ Cucco v. Pacific Finance Corp., 259 App. Div. ro33, 20 N.Y.S. 2d 779 (r940); Vee Bee Service Co. v. Household Finance Corp., 5 I N.Y.S. 2d 590 (S. Ct., I945); Kelter v. American Bankers Finance Co., 306 Pa. 483, I60 Atl. 127 (I932); Joy v. Provident Loan Society, 37 S.W. 2d 254 (Tex. Civ. App., I93I).

${ }^{16}$ Vee Bee Service Co. v. Household Finance Corp., 5 I N.Y.S. $2 d 590$ (S. Ct., I945).

${ }^{27}$ Oyster v. Longnecker, I6 Pa. 269 (I85); see Midland Loan Finance Co. v. Lorentz, 209 Minn. 278, 296 N.W. 9 II (I94I). 
tion of industry, the movement to cities, and the development of the wage system, cash credit in small sums had become a common need. ${ }^{18}$ This need was, and still is, more urgent than the desire for credit to purchase goods for which savings will not suffice. The gradual shift in the quality of the small loan problem from a social to an economic basis was not immediately recognized. Small wonder that legislatures continued to deal with it piecemeal and usually by increasingly severe prohibitions. ${ }^{x 9}$ Even now, when mass production has become a basic feature of our economy, supported by the mass consumption of wage and salary earners, we find legislatures lagging-picking at the pieces of a consumer credit system which has become confused by the entrance of widely different and virtually unregulated agencies. As separate institutions, the several types of agencies which grant consumer credit are inhibited in their evolution by their past courses of development. They strive to maintain as long as possible the features which distinguish them from their competitors. The political strength of each has tended to perpetuate an erratic, irrational system of regulation.

The one systematic plan of regulation throughout the period of haphazard legislation has resulted from the work of the Russell Sage Foundation. From I907 to I9I6, the Foundation made a comprehensive study of the whole problem of small credits to individuals. It encouraged the enactment of various types of remedial legislation and observed the results. From I9I6, when it published its First Draft of Uniform Small Loan Law, until I942, when the Seventh Draft was issued, it participated continuously in many states in the process of perfecting the system of regulation and adapting it to changing conditions..$^{20}$ By Igr6 the Foundation had determined that the regulation of the commercial sources of credit could be accomplished only by relaxing the usury laws and increasing the maximum permitted rate sufficiently to cover the risk and expense of making such

${ }^{28}$ Kelso, Social and Economic Background of the Small Loan Problem, 8 Law \& Contemp. Prob. I4 (I94I); Mors, Rate Regulation in the Field of Consumer Credit, I6 J. of Bus. of Univ. Chi. 5I (I943); Eubank, A Case Study of the Effects of Consumer Credit upon the Family, I96 Annals 2II (r938); Mottershead, op. cit. supra note 5.

19 Gallert, Hilborn, and May, op. cit. supra note 2, cc. iii, iv; Robinson and Nugent, op. cit . supra note 2, c. iv.

${ }^{20}$ Nugent, The Changing Philosophy of Small Loan Regulation, Ig6 Annals 205 (I938); Bradway, The Development of Regulation, Ig6 Annals I8I (I938). The Seventh Draft, which was published by the Russell Sage Foundation in 1942, resembles the Model Consumer Finance Act which was published by the National Consumer Finance Association, "as approved in principle, October I, I948." See the foreword to this publication.

It is noteworthy that the four states which do not have general usury laws have nevertheless adopted the principle of rate control and other regulation of small loans. These states are Colorado, Maine, Massachusetts, and New Hampshire. California may also be listed as being in this class. See Nugent, The Loan-Shark Problem, 8 Law \& Contemp. Prob. 3, I2 (I94I). 
loans and to provide a profit. ${ }^{2 x}$ It was concerned with fostering a legitimate source of consumer credit and with obtaining effective and enforceable regulation of the creditor and his practices, in the public interest. If statutory provisions necessary to accomplish these ends caused the price to be stated in an unattractive form, that either did not concern the Foundation or may have been considered to be an advantage.

The Uniform Small Loan Law has the following principal features: ambit fixed by a maximum size of loan, originally $\$ 300$; licensing system for lenders; licensees subjected to special penalties and state surveillance; non-licensees who exact usury subjected to severe special penalties; a requirement for detailed statement to the borrower of the salient facts of the loan; compulsory acceptance of prepayments; prohibition of confession of judgment; strict regulation of wage assignments; and prohibition of numerous devices of concealment or evasion, such as false or misleading advertising. Banks, industrial banks, building and loan companies, credit unions, pawnbrokers, and sometimes other special agencies having a statutory background are exempted from the penalties and denied the privileges of the Act. The most important feature of the USLL is the permitted maximum rate. Originally this was $3 \frac{1}{2}$ per cent a month computed as simple interest on the declining unpaid principal balances up to $\$ 300$. Over the years, this maximum rate attracted large amounts of capital. In I935 the Foundation recommended a reduction to $2 \frac{1}{2}$ per cent a month on the portion of the unpaid balance exceeding $\$ 100$. In I 942 a further reduction was recommended to 3 per cent on the portion of the unpaid balance up to $\$ 100$ and 2 per cent on any portion over $\$ 100$.

As Professor Bogert relates, after I9I6 statutes based on the USLL were rapidly enacted by many states. Sometimes radical departures from the Uniform Draft occur in state acts, so it is unsafe to generalize as to details, but it is possible to classify the state acts as to their over-all effectiveness. The Act, in workable form, is now in effect in thirty states, Hawaii, and the Dominion of Canada. ${ }^{22}$ Deficient and only partially effective versions are in force in four additional states..$^{23}$ In sixteen of the

2x Nugent, The Changing Philosophy of Small Loan Regulation, I96 Annals 205, 207 (r938); Ham, Small Loan Legislation, Progress and Improvement (Russell Sage Foundation, I922).

32 Hubachek and Barrett, Reference List of Small Loan Legislation (National Consumer Finance Association, I948). Since 1944, Missouri has barred special interest statutes by a constitutional provision, and New Mexico has enacted a small loan law.

${ }^{23}$ Nev., N.M., Okla., Wyo. New Mexico was just transferred from the workable list to the defective list because of a 1949 law concerning the sale of life and disability insurance in connection with loans.

Comprehensive small loan laws in four additional states are rendered nugatory by maximum rates of charge too low to permit commercial operations: Ala. (8 per cent); Ark. (ro per cent); 
thirty states, ${ }^{24}$ some form of small loan law has been in force for thirty years or more; in seven ${ }^{25}$ other states, for over twenty years. ${ }^{26}$

The USLL originally controlled the great bulk of the consumer credit which then existed, that is, the small loan to the individual. There were only two lending' agencies of considerable significance: the "loan shark" whom it barred and punished, and the licensed lender whom it fostered and regulated. The subsequent development of new and unregulated consumer credit agencies and the entry into the consumer credit business of established but unregulated commercial lenders have created the need for a new and broader code.

It is not contended in this article that the system and standards set up by the USLI are the best for the new agencies. They have been dealt with here because that law constitutes the only available datum point by which to determine the drift of recent legislation.

The most prevalent recent devices to increase ostensible rates of charge on consumer installment credit have been the use of discounts and fees without refunding unearned portions thereof, and the sale of insurance to debtors. A discussion of them will illuminate the background of recent legislation.

Discounting. - The history of the discounting device explains its prevalence and the fact that so many bank and industrial loan laws have legalized it. Originally, the industrial loan companies depended on the fiction of selling the applicant for a loan an investment certificate and applying his installment payments to the purchase price thereof rather than to the principal of the loan. Later, many commercial banks adopted the same plan but put the installment payments in a special account which was

Ga. ( $x_{\frac{1}{2}}^{2}$ per cent per month); Tenn. ( 6 per cent plus fee not exceeding I per cent per month). To these four can be added the District of Columbia, which since r $9{ }^{3} 3$ has had a rudimentary small loan law which is inoperative because of a maximum rate of I per cent per month. For inadequacy of these rates, see Dumas, Tro Anti-Loan Shark Drives (Junior Bar Conference, American Bar Association, r947); Report of the House Committee on the District of Columbia on Small Loans, 72 d Cong. rst Sess. (I932); Meador, Loan Sharks in Georgia (Junior Bar Conference, American Bar Association, I948); Special Report for the [Virginia] Corporation Commission of Pertinent Facts with Respect to and Methods of Determining the Rate of Return to the Small Loan Business, pp. 37, 38 (I948); Nugent, Three Experiments with Small-Loan Interest Rates, I2 Harv. Bus. Rev. 35 (I933). The following states have constitutional provisions relating to interest rates which bar enlightened consumer credit legislation: Ark., Okla., Tenn., Tex. Va.

24 Ariz., Colo., Conn., Ill., Ind., Me., Md., Mass., Neb., N.H., N.J., N.Y., Ohio, Pa., Utah,

23 Fla., Iowa, La., Mich., R.I., W.Va., Wis.

${ }^{26}$ The remaining seven of the thirty states are: Calif., Idaho, Ky., Minn., Ore., Vt., Wash. The states which have not adopted the uniform law in any form are: Del., Kan., Miss., Mont., N.C., N.D., S.C., S.D., Tex. Missouri in r927 adopted a law patterned after the uniform law, but it was nullified by the Missouri Constitution of 1945 . 
not credited to the loan until it equaled the face amount of the note. Both usually took a note which included the full interest in its principal amount, and subtracted (discounted) the interest from the face of the note before giving the borrower the net amount. ${ }^{27}$

Banks and industrial loan companies had to use these methods to obtain a workable rate of charge. ${ }^{28}$ They drew back from the blunt and open statement of the actual over-all rate of charge so shocking to the popular "six per cent per annum" concept; thus the discount and the fee were used to augment the lender's income without stating the true percentage rate. With these methods has come a train of abuses requiring corrective measures such as mandatory refunds for prepayment.

Eight per cent discount returns the borrower $\$ 92$ for a $\$$ Ioo note which requires the repayment of $\$ 8.33$ per month for a year. Questions at once arise: What is the "amount of the loan" for purposes of solicitation and for computations to determine compliance? What happens when the borrower prepays by cash or renewal? He has contracted to repay, as though it were principal, $\$ 8$ more than he received. Does he still pay it if he retires his note at the end of five months?

The 8 per cent, so discounted, is slightly under twice that percentage in terms of true interest. ${ }^{29}$ If the installment credit is extended for two years, the deduction is $I 6$ per cent, the true rate of charge increases in an even larger ratio, and the need for refunding is correspondingly increased. When prepayment without refund occurs very early in the transaction, the multiplication of the true rate of charge results in a greatly increased percentage rate.

When a fee is added to the discount, the result is the same as though the amount of discount were increased. A 4 per cent fee and an 8 per cent dis-

${ }^{27}$ Consumer Credit 202-7 (American Institute of Banking, r945); Chapman, Commercial

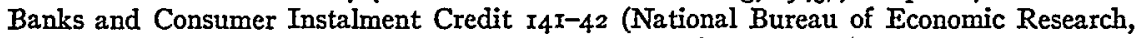
1940); Saulnier, Industrial Banking Companies and Their Credit Practices $9 \circ$ (National Bureau of Economic Research, I940); Harold, Industrial Banks, I96 Annals I42, 143-44 (I938); Younggren, Usury-Evasion Devices-Commercial Banks, 29 Ill. Bar. J. 409 (I94r); United States v. Palmer, 28 F. Supp. 936 (N.Y., I930); Connor v. Minier, rog Cal. App. 770, 288 Pac. 23 (1930); Columbus Industrial Bank v. Rosenblatt, III Conn. 84, I49 Att. 209 (I930); Mesaba Loan Co. v. Sher, 203 Minn. 589, 282 N.W. 823 (I938); Morris Plan Co. of New York v. Osnato, I23 N.Y. Misc. 428, 204 N.Y. Supp. 829 (S. Ct., I924); National City Bank of New York v. Levine, I55 N.Y. Misc. 132, 277 N.Y. Supp. 664 (Mun. Ct., r933).

${ }^{28}$ Mors, Commercial Banks and Competitive Trends in Consumer Instalment Financing, 2I J. of Bus. of Univ. Chi. I33, I35 (I948).

${ }_{29}$ Consumer Credit 223 (American Institute of Banking, I945) states: "The true, or actuarial, interest rate is based on the amount of principal outstanding (net amount advanced) from month to month. For example, take the $\$ 100$ personal loan payable in twelve equal monthly instalments which was discounted at $\$ 6$, or $6 \%$ flat. The net amount advanced, or principal, is $\$ 94$, the actuarial, or true, rate of interest is $\mathrm{rr} .58 \%$ per annum, or $0.965 \%$ per month." The mathematical calculations which precisely prove this rate follow this quotation. 
count on a I2 months' installment credit create a true rate of charge of 24 per cent per annum. The need for a refund or credit commensurate with the unexpired period of the time originally contracted for is much the same..$^{30}$

It should be noted, parenthetically, that, on the basis of very broad. averages, the charges of banks and industrial loan companies for typical consumer installment credit are lower than the charges of regulated consumer finance (small loan) companies. True comparisons, however, are almost impossible because of inherent differences. The average amount of the individual transaction by banks and industrial loan companies is considerably larger than that of small loan companies. The credit worthiness of the average debtor to the former agencies is better. Moreover, the rates of charge by small loan companies fall within a comparatively narrow range so that an average is a relatively true indicator, while the rates of charge of the other two agencies vary widely between different lenders and different customers of the same lender. In a substantial part of the business done by many lenders who use the discount and fee method of charging, fortuitous circumstances such as the incidence of prepayment, refinancing, and delinquency determine the true rate of charge..$^{3 \mathrm{I}}$

That the abuses possible under a discount or a discount and fee system have aroused critical legislative interest is demonstrated by the laws passed during the last four years directed to the subject of refunds of unearned charges written into the amount of the debt at its inception. The simple interest system, not to be written up in advance or taken until earned, automatically eliminates all questions of refund. It will be interesting to observe whether legislatures continue to try to correct an error or stop enacting the error in the first place. The answer probably lies in the question of how firmly the discount and fee system is embedded in our traditions and financial institutions. That is another way of saying, how important is it to conceal the true percentage rate of charge on consumer installment credit?

Insitrance. - Insurance has become a popular feature in connection with installment credit, both because it provides protection to the lender and the borrower in case the security is destroyed or the borrower dies and be-

${ }^{30}$ Interim Report of the [N.Y.] Joint Legislative Committee on Installment Financing (March 2, I948); Summary Report of the Joint State Government Commission to the General Assembly of Pennysivania, p. I7 (March 2I, I947); Phelps, Monopolistic and Imperfect Competition in Consumer Loans, Journal of Marketing 382, 389 (April x944); Agostini v. Colonial Trust Co., 36 A. 2d 33, 39 A. 2d 406, 44 A. 2d 21 (Del. Ch., 1944). Some of these studies show that the problem of adequate refunds is also inherent in sales finance transactions where the "credit price" includes in its original face all credit charges and often others such as insurance.

${ }^{3 x}$ Mors, op. cit. supra note 28 , at 146 . 
cause it can be a source of an extra and hidden profit. The profit may come to the lender as a commission for selling the insurance or as a rebate of part of the premium or as a favorable "experience rating." When insurance is required for the purpose of obtaining a charge in addition to the maximum legal interest rate, it is a device to evade the law.

There are three elements which make the sale of insurance by installment creditors a puzzling problem of regulation and enforcement. First, since insurance is frequently a bona fide requirement of the creditor or a bona fide desire of the debtor, it is often difficult to determine whether its use is a subterfuge. Second, if the debtor really needs insurance, there is theoretical justification for permitting the lender to sell it, provided the premium, the commission, and the coverage are standard. Third, if the use of insurance is to any extent a subterfuge, it is difficult to regulate because of the lack of a definite standard of bona fide values for the various types of insurance coverage which may be provided.

Suffice it to say that the use of insurance sales by consumer installment creditors presents today a most serious threat to any systematic plan of regulation in the public interest. Evasions of rate maxima by that device strike at the base of credit regulation.

The more obvious examples of insurance sales to increase creditors' profits are "credit life insurance" and "credit health and accident insurance," available only in connection with consumer credit. Generally, they are sold through the creditor or his affiliate to most of the customers and the commissions are one-half or more of the premiums. The premiums for life, health, and accident coverage combined are about $\$ 7.50$ for each \$oo of a debt payable over one year.

Even among stringently regulated small loan companies the matter of insurance sales has been a battlefield of opposing philosophies, mainly because of the difficulty of separating the good from the bad. One school says, "The borrower will have to buy insurance to obtain a loan secured by his car; why shouldn't the lender be permitted to sell him standard coverage at standard rates and get the profit?" The other school says, "Well and good if there was any way to be sure that only such sales as you describe are made, but everyone knows that if they are permitted there will be unconscionable abuses difficult to detect and impossible to prevent. Moreover, a great part of the gross income of the lender will be his undisclosed commissions. He will advertise only a part of the true rate of charge. The free and honest competition which is the consumer's salvation will revert to a battle of creditors' wits in which the slickest will win. Complete and candid disclosure is the sine qua non in consumer credit." 
The honest and necessary element of insurance has been prostituted until the corrective legislation may overshoot the mark as widely as the abuses have exceeded the true need. Recent laws on the subject of insurance sales show a continuation of the effort to confine the consumer creditor's charges to those disclosed in his published rate.

The early legislation regulating the installment loan activities of commercial banks and industrial loan companies effected little change in their practices. Most industrial loan or industrial bank acts have been based on the use of discounts and sometimes fees..$^{32}$ Recent acts legalizing the entry of commercial banks into the consumer loan business have usually permitted the same practices, ${ }^{33}$ but often safeguarded by restrictive provisions. As bona fide installment sales are free of the usury laws, ${ }^{34}$ the credit charge and other items are added to the cash sale price of the goods, and recent sales finance acts permit this practice.

Laws enabling and sometimes regulating these lending agencies were generally drafted by the agencies themselves. Under these laws the total actual charge for the credit is stated in several parts, obscuring the amount as well as the rate of charge. The early laws were procured merely for the purpose of relaxing the usury maxima. The need of regulation to protect the borrower was not at first recognized. It was only after experience under relaxation of the usury laws without regulation that the necessity for controls of creditors' practices became apparent. Recent regulation has been in the form of a more definite statement of the maximum rate, refund of unearned charges upon prepayment, a more specific statement of the amount of service fees, limitations on the service fee, and prohibitions of extra charges. In some recent instances, supervision in the form of licensing and inspection has been provided for.

A review of the legislation which was passed in the years $1945^{-1948}$ reveals that twenty-one states have enacted one or more significant regu-

${ }^{32}$ Industrial Banking Legal Digest (Consumer Banking Institute, I945).

33 Twenty-three states have statutes under which banks may make installment loans at a greater rate of interest and charges than permitted by their general usury laws. Sixteen of these apply only to banks. Seven are not restricted to banks but are available to certain other lenders making installment loans. Seventeen of the twenty-three were enacted during or since I936. The twenty-three states are: Ala., Ariz., Del., Fla., Ga., Iowa, Ky., Md., Mich., Minn., Miss., Neb., N.J., N.Y., N.C., Ohio, Pa., S.C., Tex., Va., W.Va., Wis., Wyo. In addition, three states (Conn., Me., Mass.) have specifically authorized savings banks to make "personal loans."

34 Provided, of course, that the course of dealing does not make the vendor a mere agent for the sales finance company in extending the credit. For exemption of installment sales from the usury laws, see Berger, Usury in Installment Sales, 2 Law \& Contemp. Prob. 148 (1935); Rogers, Sale of Property on an Installment Payment Basis, ro Time Sales Financing, No. 2, pp. 7-9, 26 (I945); Annotation: Finance charge in connection with conditional sale contract as usury, I43 A.L.R. 238 (I943). 
latory laws applicable to some part of consumer installment credit. These enactments fall under three general headings: acts enlarging the area of the small loan law; acts regulating other types of creditors in a manner similar to small loan laws; other evidences of a trend toward symmetrical treatment of the various credit agencies and methods.

Acts Enlarging the Area of the Small Loan Lare.-The $\$ 300$ size limit on loans to which the small loan laws usually apply was first adopted about 35 years ago. Recognizing the decrease in the value of the dollar and other factors, four states increased the size of loan to which their small loan laws apply from $\$ 300$ to $\$ 500,35$ thus re-applying these laws to the part of the consumer credit field to which they originally applied.

Five states enacted small loan law amendments or revisions of varying importance. ${ }^{36}$ Two other states replaced inadequate and fragmentary small loan laws with new laws which made little if any improvement. ${ }^{37}$

Acts Which Regulated Banks, Industrial Loan Companies, and Others in a Manner Similar to Small Loan Laws.-Under this heading are included laws requiring refunds of unearned charges, restricting or regulating the sale of insurance, and subjecting sales finance companies to regulations heretofore ordinarily imposed only on lenders.

a) Bank and Industrial Loan Lares. Thirteen states enacted one or more laws regulating banks or industrial loan companies. In seven states, nine laws related to banks. ${ }^{38}$ In nine states, ten laws related to industrial loan

${ }_{35}$ Illinois: Ill. L. 1947, p. II52. Michigan: Mich. Pub. Acts 1947, No. I30. New Mexico: N.M.L. I947, c. 174. New Jersey: N.J.L. 1948, c. 7 I. For 1949 legislation see note 60 infra.

${ }^{36}$ California: Cal. Stat. I945, cc. I220 and I22I (loans over $\$ 5, \infty 0$ exempted from important restrictions), 395, 396, and 902 (commissioner's discretionary powers strengthened). Connecticut: Conn. Pub. Acts 1945 , c. $45^{6}$ (loans limited to 18 months, and interest rate reduced after 20 months to I per cent a month; refinancing of balances unpaid after 20 months prohibited). Massachusetts: Mass. Acts I946, c. IIg (small loan rate reduced to 2 per cent a month), I74, 223 (small loan rate a year after maturity limited to 6 per cent a year). Utah: Utah L. I945, c. $x_{5}$ A, Utah Rev. Stat. Ann. (Supp. r947) Tit. 7, c. 8a, \$\& 7-8a-I to 7-8a-24 (revised small loan law; right to require and sell insurance on a restricted basis granted). Virginia: Va. L. I946, c. 335 (commissioner authorized to reduce small loan rate).

${ }^{37}$ Alabama: Ala. Gen. Acts I945, No. I59. Wyoming: Wyo. L. I945, c. r28, Wyo. Comp. Stat. (r945) c. 39, art. II, $\$ \$ 39$-IIIr, 39-III2.

${ }^{38}$ Iowa: Iowa Acts 1945, c. 213, Iowa Code (1946) $\$ \S 529$.I to 529.13 (new installment loan law: $\$ 2,5 \infty$ loan limit, authorized charge of $\$ 6$ a year per $\$ 100$, or I per cent a month, refunds required, advertising regulated). Kentucky: Ky. Acts I946, c. 60, Ky. Rev. Stat. (I948) $\$ 287.215$ (new installment loan law: $\$ 5,000$ loan limit, rate of $\$ 6$ per $\$$ roo per year on first $\$ 2,000$ and $\$ 5$ per $\$ 100$ on balance, refunds required, charges except fines and recording fees prohibited). Massachusetts: Mass. Acts I945, cc. I97, 407, Mass. Ann. Laws (I948) c. $168, \S 54$ (savings banks permitted to make personal loans up to $\$ 1,000$ at rates to be approved by commissioner). M I innesota: Minn. Stat. (Mason, Supp. I946) $\$ \$ 7774-71$ to $7774-75$ (new installment loan law: $\$ 500$ loan limit, 6 per cent a year discount and $\$ 3$ minimum charge permitted, refunds required, charges for defaults, recording, and insurance allowed, loan statement required); Minn. L. I947, c. $3^{14}$ (loan limit increased to \$I,500). New Jersey: N.J.L. 1945, c. 208 (refund required); N.J.L. I948, c. 67 , art. I2 (revised law: loan limit raised from $\$$ I,000 
companies. ${ }^{39}$ In each case the legislation was a step toward codification, as it either regulated a portion of the field which had not been regulated before or it added new restrictions to existing regulations. Generally, the restrictions added to existing laws reflected experience under enabling acts which had originally been adopted without regard to the consequences of increasing the maximum rate without applying adequate regulations.

b) Sales Finance Lares. Six states and Quebec enacted laws concerning the sales finance business. Five were regulatory laws where none had existed before..$^{4^{\circ}}$ One was a provision for an interim study committee. ${ }^{4 \mathrm{~T}}$ One was both a provision for an interim study committee and a provision for interim legislation which has been continued twice. ${ }^{42}$

Of the five sales finance laws enacted, all required a refund except that of California. The New York interim legislation for the benefit of banks and industrial loan companies required the charges to be computed on unpaid balances subject to a minimum charge of $\$ 5$, and the report of the

to $\$ 2, \infty 00)$. New York: N.Y.L. 1946, c. 88 (refund requirement for banks, industrial banks, and credit unions). Pennsylvania: Pa. Stat. Ann. (Purdon, Supp. r948) Tit. 7, \$ 8I9-rooI (new installment loan law: 6 per cent a year discount on loans up to $\$ 3,500$ permitted, refunds required, fines, insurance, recording, and attorney's fees permitted, advertising which states charges required to include payment chart or statement of rate).

${ }^{39}$ California: Cal. Stat. 1945 , c. 1494 (industrial finance charges changed from discount and fee method to monthly percentage on unpaid balance method, change-over completed from discount and fee method which began in 1940, Cal. Stat. 1940, c. 34, and Cal. Stat. I94I, c. II87). Delaware: Del. L. I945, c. 237 (amount of discount permitted under 6 per cent discount law limited to I8 per cent [three years]). Maryland: Md. L. I945, c. 932, Md. Ann. Code (Flack, Supp. 1947) art. II, \$§ 153 to I95 (new law: discount and fee on loans up to $\$ 1,500$ permitted). Minnesota: Minn. L. x945, c. 439 (refund required). New York: see note 38 supra. Pennsylvania: Pa. L. I947, No. 288 (loan limit increased from $\$ x, 000$ to $\$ 2,000$, interval between fees reduced from 8 to 4 months). Texas: Tex. L. x945, cc. x94 and $x 95$ (oblique recognition of typical industrial bank operation). Utah: Utah. L. 1945, c. 73 (repetition of service fee oftener than 6 months prohibited); Utah L. 1947, c. 62 (industrial loan companies permitted to write automobile insurance during interim period of 2 years). Wisconsin: Wis. L. I947, c. 462 , amending Wis. Stat., c. Ix5 (very old Discount Loan Law revised: loän limit raised from $\$ x, \infty)$ to $\$ 2, \infty 00$, discount rate lowered, fee added, provisions requiring certificate of convenience and advantage eliminated).

${ }^{40}$ California: Cal. Stat. I945, c. I030 (fragmentary motor vehicle sales finance act providing maximum rate and some disclosure). Connecticut: Conn. Gen. Stat. (Supp. I947) cc. $25^{\mathrm{h}}$ and 233 (installment sales up to $\$ 2,000$ regulated, no maximum rate, disclosure and refunds required). New Jersey: N.J.L. I948, c. 419, N.J. Rev. Stat. (Supp. x948) §§ I7: I6B-I to $I_{7}: \mathrm{I} 6 \mathrm{~B}-12$ (installment sales up to $\$ 3, \infty 00$ regulated, no maximum rate, disclosures and refunds less \$ro acquisition charge required). Pennsylvania: Pa. L. 1947, No. 476 (stringent motor vehicle sales finance act, following recommendations of Joint State Government Commission [bills to create consumer credit commission failed]). Quebec: II Geo. VI, c. 73 (I947) (minimum down payment, refunds, and disclosures required, maximum charge fixed).

4 Michigan: Sen. Con. Res. No. 44,3 d spec. sess. (adopted April 26, 1948).

42 New York: Sen. J. Res. (adopted March 17 , I947); N.Y.L. I947, c. 487 (banks, trust companies, and industrial banks authorized to charge 12 per cent a year on unpaid balances or a minimum of $\$_{5}$ on purchase of installment paper arising from sales of personal property), extended by N.Y.L. 1948, c. 219 and N.Y.L. 1949, c. 494 . 
New York interim committee recommended legislation to require refunds in connection with all sales finance transactions. ${ }^{43}$ There are now sales finance laws of varying comprehensiveness in at least eleven states. ${ }^{44}$ Most of them require refunds and disclosure of the more important facts of the transaction, such as the down payment, the finance cost, and the monthly payments required. Some have other important features, such as maximum rates, licensing, and restrictions on dealer participation.

c) Refund Requirements. The most noteworthy legislative development during this period has been recognition of the need for a refund requirement when the statute permits interest or other charges to be taken or written into the principal balance in advance. The necessity for refunds arises largely from the fact that consumers are prone to refinance their debts one, two, or more times before getting out of debt. Loans are made generally for I2, I8, or 24 months, and the charge, when taken or written into the principal balance in advance, is for the full term of the loan. If the borrower refinances his loan after six months, a failure to refund results in a greatly increased rate of charge. Of course, if charges are taken only after having been earned, there is no need for refund.

Refund requirements of varying effectiveness have been added to existing laws authorizing increased rates to banks and industrial loan companies. They have also been included in new laws restricting sales finance companies, even when the law did not set a maximum rate. They have not been added to the laws regulating small loan companies because, with minor exceptions, all small loan laws require charges to be computed and paid on the unpaid balances at the time of each payment, and prohibit discounting or taking charges in advance or compounding.

In eight states, bank or industrial loan legislation has required a refund of unearned charges when the loan is prepaid in full. ${ }^{45}$ New York imposed the refund requirement on commercial banks, industrial banks, and credit unions in the same amendatory law. Pennsylvania imposed refund requirements on banks, industrial loan companies, and sales finance companies in separate laws enacted about the same time. Minnesota enacted separate refund laws for banks and industrial loan companies. Except for

43 Ibid. Interim Report, op. cit. supra note 30.

44 In addition to those listed note 40 supra these are: Indiana: Ind. Stat. Ann. (Burns, 1933), $\$ 8$ 58-9or to 58-934. Maine: Me. Rev. Stat. (x944) c. 56, $\$ 264$. Maryland: Md. L. x94x, cc. 476, 85I. Massachusetts: Mass. Ann. Laws (Supp. 1948) c. 255. Michigan: Mich. Stat. Ann. (Henderson, Supp. I947) §§ 9.1482, I9.415(I) to I9.415(I4). New York: N.Y. New Personal Property Law (McKinney, Supp. I948) \& 64a. Wisconsin: Wis. Stat. (I947) \& 218.01.

${ }^{45} \mathrm{Cal}$. (industrial loan companies); Iowa (banks); Ky. (banks); Md. (industrial loan companies); Minn. (banks and industrial loan companies); N.J. (banks); N.Y. (banks and industrial banks); $\mathrm{Pa}$. (banks). See notes 38,39 supra. 
Texas, ${ }^{46}$ no legislation which authorized an increased rate of charge for installment loans failed to impose either a refund requirement or a requirement for computing charges on unpaid balances. Of the eight states enacting refund legislation, five ${ }^{47}$ added the requirement to existing laws, indicating that experience had demonstrated the need for it. The refund amendment to the California Industrial Loan Act ${ }^{48}$ shifted the basis of the charges from the discount and fee to the unpaid balance method, but with permission to pre-compute the charge subject to a refund requirement.

Three states imposed a refund requirement by administrative regulation. 49

Three states either eliminated service fees or restricted the right to repeat a service fee in connection with refinancing..$^{50}$ Several states authorized fees, but under restrictions limiting repetition of the charge in connection with refinancing. ${ }^{. x}$ Elimination or restriction of a service fee is the same type of reform as a refund requirement.

d) Insurance. Three states enacted insurance laws of general application, prohibiting lenders and finance companies from requiring customers to purchase insurance from a designated insurance agent as a condition of the transaction. ${ }^{52}$ These laws treat all classes of lenders alike for the purpose of the restrictions which they impose-further evidence of a trend toward codification. Laws or amendments of at least three states, however, authorized the requirement and sale of insurance on a restricted basis. ${ }^{53}$

e) Advertising. The Illinois honest advertising statute was amended to apply specifically to loans, credit, and interest as well as merchandising. The amendment was similar to a New York amendment adopted in I940.54

Other Evidences of a Trend toward Symmetrical Treatment of the Various Credit Agencies and Methods.-A clear instance of this trend was provided when refund requirements were imposed "straight across the board" in New York in one amendatory act which applied to several different portions of the consumer credit business. Another evidence of codification is the new Wisconsin Consumer Credit Review Board, established by a stat-

${ }^{6} 6$ See note 39 supra. $4^{8}$ See note 39 supra.

${ }^{47}$ Cal., Minn., N.J., N.Y., Pa. See notes 38, 39 supra. $\quad 49$ Del., Ind., Utah.

${ }^{50} \mathrm{Cal}$. and Utah (industrial loan laws); N.M. (small loan law).

${ }^{5 x} \mathrm{Md}$., $\mathrm{Pa}$., and Wis. (industrial loan laws).

${ }_{52}$ Michigan: Mich. L. I947, Act No. 67. New Jersey: N.J.L. I948, c. 298. Nezv York: N.Y.L. I947, c. I53.

${ }_{53} \mathrm{Md}$., Utah, and Wis. (industrial loan laws; see note 39 supra); Utah (small loan law; see note 36 supra).

54 Ill. L. I945, p. 680; N.Y.L. I940, c. 356. 
ute requiring industry representation of three branches of the consumer installment credit field. .5

Most of the legislation authorizing charges either prohibited all charges in addition to those specifically authorized or enumerated carefully defined exceptions, thus closing the door to a variety of subterfuges to defeat the rate maximum. As most small loan laws have always done this, the tightening of other types of laws has tended to reduce the differences in treatment.

Developments in three other states further illustrate this trend toward similarity of treatment:

a) Indiana. Consolidated rate hearings for small loan companies, industrial loan companies, sales finance companies, and pawnbrokers, together with other unified administrative action in Indiana recognized the desirability of treating the installment credit agencies on as nearly as possible a comparable basis. The trend toward uniformity was further evidenced by the fact that administrative regulations applicable to small loan companies were decreased and those applicable to other installment credit agencies were increased. In addition, the I947 Legislature provided for a commission to be appointed by the Governor to make a general study of the installment credit business..$^{56}$

b) Missouri. The new Missouri constitution is a dramatic illustration of an effort to force codification. Missouri is now under a constitutional necessity to codify its interest laws and treat all classes of lenders substantially the same for the purpose of statutes fixing maximum interest rates. The effect of the new constitution was to destroy all existing legislation authorizing rates of interest in excess of the general maximum, 8 per cent a year, fixed by the usury law. Missouri has been without a small loan law or any other regulatory interest law based on lender classification since July I, I946, when the new constitution became effective. The Missouri legislature has been unable to solve this problem despite a steady succession of bills in regular and special legislative sessions beginning in $19455^{57}$

c) Keniucky. Kentucky limited pawnbrokers' charges to $3 \frac{1}{2}$ per cent per month computed as simple interest on unpaid principal balances. ${ }^{58}$

${ }_{55}$ Wis. L. $x 947$, c. 4 Ix.

${ }^{56}$ Industrial Loan \& Invest. Reg. No. $x$ (adopted Nov. 30, 1945); Ind. L. I947, c. 39 r.

57 Mo. Const. (r945) Art. III, $\delta 44$; Household Finance Corp. v. Shaffner, 356 Mo. 808, 203 S.W. $2 \mathrm{~d} 734$ (1947); State on Inf. of Taylor v. Salary Purchasing Co., 2I8 S.W. $2 \mathrm{~d} 57 \mathrm{I}$ (Mo. S. Ct., I949).

${ }^{88} \mathrm{Ky}$. Acts 1946 , c. 216 ; Ky. Rev. Stat. (1948) $\S \S 226.050(2)$, 226.080, 226.090, 226.990(4). A recent case involving this law suggests that pawnbrokers have a constitutional right to a rate of charge adequate to remain in business. Peel v. Dummit, 214 S.W. 2d 605 (Ky. App. Ct., 1948). 
This record of recent legislation can be summed up in three general propositions: by slow and faltering steps society is bringing consumer creditors toward a harmonious system of regulation; the strongest emphasis is on the maximum charge the creditor will be permitted to take; and advancement toward a code of regulation has been forced by legislative recognition of isolated evils. The opinion is added that many additional single steps must be taken toward unification of the diverse regulatory measures which now apply to the different consumer creditors, before a scientifically conceived code will appear which will have a reasonable chance of understanding and adoption.

In recent years certain significant non-legislative trends have also appeared. Small loan companies have expanded the portion of the consumer credit field in which they operate by increasing their loan sizes substantially above $\$ 300$. This was partly the result of the increase in wage and price levels and partly for competitive reasons. Loan sizes have increased not only in states where the maximum size under the small loan law has been increased above $\$ 300$ but also in other states where larger amounts can be lent under other laws. In at least eleven states, small loan licensees conduct an affiliated business of lending in amounts over $\$ 300$ under such other laws. These eleven states, plus the eight states which permit larger loans under the small loan law, make nineteen states in which a larger loan business can be conducted. ${ }^{59}$ Two more states, Connecticut and New York, were added to the list as of July I, I949, as the result of I949 amendments increasing the ambit of their small loan laws from $\$ 300$ to $\$ 500.60$

The above development is only one example of the overlapping and intermingling of consumer credit agencies. Similarly, most commercial banks which extend consumer credit do so on both a lending and a sales finance basis. This has been characteristic of banks since the early I930's when they began to enter the field in large numbers. ${ }^{6 x}$ Another example is the fact that several of the larger and many of the smaller sales finance companies have obtained small loan licenses. Similarly many industrial

${ }^{59}$ Small loan laws: Cal. (no loan limit); Ill. $(\$ 5 \infty)$; Mich. $(\$ 5 \infty) ;$ Neb. $(\$ 1, \infty)$; N.J. $\left(\$_{5} \infty\right)$; N.M. $\left(\$_{5} \infty 0\right)$; Ohio $(\$ r, \infty \infty)$; Wash. $(\$ 5 \infty)$. Hubachek and Barrett, op. cit. supra note 22. Wis.

Industrial loan and other laws: Ariz., Colo., Ind., Md., Mass., N.H., Ore., Pa., R.I., Utah,

${ }^{60}$ Conn. L. 1949, Act No. 136; N.Y.L. 1949, c. 521.

${ }^{6 r}$ See consumer credit statistics in 35 Fed. Reserve Bull. 300-I (March 1949), and similar statistics in prior Bulletins, which list commercial bank installment credits outstanding according to purpose of credit and whether it is sales credit or direct loans. See also note 4 supra. 
loan companies have sales finance departments. Some of the larger small loan companies and many of the smaller ones (and even a few credit unions) are in the sales finance business to some extent.

The so-called dual business clause of the USLC has been an important factor in the development of overlapping activities. As conceived by the Russell Sage Foundation in 1932, this clause was designed to prevent the small loan business from being operated as an adjunct of another business when the combination facilitated abuses, e.g., credit furniture stores and collection agencies. The clause prohibited a small loan licensee from engaging in any other business in the licensed office, except with the permission of the supervising official upon a finding that the joint operation would not facilitate evasion. ${ }^{62}$

This clause has been applied usually as a prohibition, but, more recent$l y$, it has been used as a regulation. The operation of the small loan business, the industrial loan business, and the sales finance business-all in conjunction with each other and in the same office-has been permitted under varying degrees of administrative restriction. The Model Act of the National Consumer Finance Association recognizes the right to conduct several businesses in the same office subject to reasonable administrative restrictions. ${ }^{63}$

The administration of the dual business clause in Wisconsin is an example of its use not only as a regulatory measure but also as a means of bringing unified standards into play. Since I944 the Commissioner of Banks has required small loan licensees to agree in writing to conform to certain regulations as a condition to obtaining permission to engage in other businesses. Under this administration, those licensed under the discount law were for a time required to state the discount charge on a basis as nearly as possible comparable to simple interest rates. When the discount law was recently amended to permit a fee, the agreement was revised to require a refund of the fee as a condition to refinancing a discount loan under the small loan law.

From the record it seems clear that there has been a drift toward the standards of the USLL in (I) imposing some degree of regulation on other

${ }^{62}$ Fifth, Sixth, and Seventh Drafts of Uniform Small Loan Law $\S$ I2.

${ }^{63}$ Section I2(a) of the Model Consumer Finance Act, op. cit. supra note 20, reads: "The business of making loans under this Act may be conducted within any office or place of business in which other business is solicited or conducted unless the Administrator, after ro days' notice to the registrant and opportunity to be heard, finds that such conduct facilitates or conceals violations of this Act and orders the registrant to desist from such conduct, but the registrant shall not be denied the right to conduct such business in an office or place of business in which there is conducted any business of a financial nature supervised by any state office or official." 
consumer credit agencies, (2) requiring refunds of charges taken in advance, (3) restricting the creditor's power to make hidden profits, and (4) forcing advance disclosure of salient facts to prospective debtors. Another trend is in the direction of enlarging the field of the small loan law by increasing the maximum size of loan to which it is applicable. Thus it appears that there has been some progress toward symmetrical treatment of the various credit agencies and methods, piecemeal and forced by circumstances rather than conceived and executed by the foresight of legislative statesmen.

Certain important considerations are often overlooked in dealing with the problems of rates and regulations for consumer installment credit. There is a widely held belief that small loan laws are an extraordinary if not unique exception to the general usury laws. This misconception may partially account for the legislative reluctance to deal realistically with the increased rate of charge required by consumer installment credit agencies. In fact, many other important types of credit agencies and transactions are excepted, some of which are entirely unregulated. ${ }^{64}$

The degree to which a general interest maximum must be relaxed to permit a consumer installment credit business to be carried on varies inversely with the size of the individual credit, whether the debt is a loan or a sale obligation. Within reasonable limits there is a fixed overhead cost of every loan which varies only slightly with the size of the loan. Obviously, at a fixed rate the dollar return on a large loan is greater than that on a small loan. A loan of \$roo repaid in twelve equal monthly installments of principal at an interest rate of $2 \frac{1}{2}$ per cent per month on unpaid principal balances returns to the lender $\$ 16.25$ of gross income, while a loan of $\$ 500$ on the same terms returns $\$ 8 I .25$. Assuming that the overhead costs of the creditor are $\$ 5$ per loan, it is apparent that he cannot make a $\$ 5^{\circ}$ loan at a direct profit and that the profit on the $\$ 500$ loan is too large.

Similarly, the degree to which the average debtor needs statutory protection varies inversely with the size of the individual credit. Though this is more elusive, it is a fact equally as important as the inverse relationship

\footnotetext{
${ }^{64}$ Barrett and Ulrich, op. cit. supra note 2, at v-vi say, "The small loan law is one of several well-established exceptions to the general usury laws. In some states there are so many statutory or judicial exceptions that in practice the general usury law effectively limits only the exceptional lender or transaction. The more important types of lenders and loans which frequently are wholly or partially exempt from usury laws include banks, credit unions, industrial or discount loan companies, building and loan associations, pawnbrokers, installment loans, small loans, loans insured by the Federal Housing Administration, loans to corporations, and demand or call loans exceeding $\$ 5000$ secured by negotiable instruments. Other important types of credit transactions are exempt from usury laws on the technical ground that they are not loans of money, such as a sale of property on credit with an increase over the cash price, and purchase of accounts receivable."
} 
between the necessary percentage charge and the size of the individual credit. By and large the degrees of necessity, unsophistication, and inadequacy of legal remedies decrease as the size of the consumer's credit transaction increases. On the occasions when the constitutionality of the USLL has been challenged, ${ }^{65}$ the principal question has been whether the special provisions of that law, which are applicable only to a special class of transactions (loans of $\$ 300$ or less), constitute a reasonable exercise of the police power. In answering this question, the appropriateness of the provisions to correct the evils existing in the special class of subject matter is the criterion. The courts have uniformly found that loans of less than some stated dollar amount are characterized by peculiar attributes calling for special protection of the debtors. While $\$ 300$ or less has been judicially determined to be an appropriate means to define the class, the question is essentially one of degree, in which the elements requiring state intervention actually shade from black to white by imperceptible stages. There is some point, however, within the proper zone for consumer installment debt regulation, at which the emphasis of regulation should shfit and the maximum permitted rate of charge should change. There may be several such points between the smallest consumer debt above the charity line and the largest consumer debt below the business line.

The growth of consumer debt into transactions of the larger amounts has complicated the problems of state regulation. Assuming that the line between the two classes of consumer installment debt falls today somewhere between $\$ 500$ and $\$ 750$, effective regulation of the smaller class can differ radically from that of the larger class of debts. The smaller class has special characteristics. Here are found the borrowers who are closest to the subsistence level. Generally they are the group most easily imposed upon, both because of lack of reserves upon which they can draw to assert whatever rights the law gives them and because they are most lacking in business experience and judgment. Also, these are the borrowers who are most apt to become public charges if they are imposed upon by creditors. The community has more than an ordinary interest in their protection. ${ }^{66}$

${ }_{6 s}$ People v. Stokes, 28I Ill. I59, I I8 N.E. 87 (r9 77 ); Kelleher v. Minshull, Ix Wash. 2d 380 , II9 P. $2 \mathrm{~d} 302$ (I94 I), and cases cited; Hubachek, op. cit. supra note I2, at I6-26 (citing cases).

${ }^{66} \mathrm{Kelso}$, op. cit. supra note I8; Cobb, Consumer Credit as It Comes to the Legal Aid Society of New York, I96 Annals I98 (r938); Eubank, op. cit. supra note I8.

Typical conditions where small loans were unregulated were described by one court as follows: "The population of Jefferson county is estimated to be 365,000 , of which about 50,000 or 60,000 are wage-earners, with between 200,000 and 300,000 dependents. To live and support their families they require an extension of credit upon peculiar terms to meet their needs and abilities to pay. They occupy rented property; the rent payable by the week. The county is the center of extensive industries, commerce, manufactures, transportation, retail and wholesale businesses. There are within the county between 70 and 80 small cut-rate loan offices, en- 
In this smaller loan class, it is essential to bar the outright loan shark by careful definitions and heavy penalties. That need is less in the larger class. Comparatively strict surveillance by a state official is indicated in the smaller group. Certain minor devices of evasion which are likely to be practiced on the unsophisticated small debtor must be dealt with specifically in the smaller transactions, but such provisions may be waived or modified for the larger ones. Discretionary licensing provisions may be moderated for lenders engaged mainly in the larger transactions who can be counted on to make the smaller loans at comparatively low rates.

Another element distinguishes the two classes of consumer debt-the arithmetical effect of a high rate of charge. The escalation of the true rate of charge which is caused by discounting or compounding 6 per cent per annum is not nearly as rapid or as burdensome as the same practices would produce at I 8 per cent or 24 per cent per annum. A fee of I per cent of the loan may be taken much more frequently than one of 4 per cent with less cumulation of the resulting true rate of charge. The safeguards which must be thrown around the comparatively low rate of charge necessary for a $\$ 75^{\circ}$ credit can be less stringent than in the case of the higher rate necessary for the smaller credits.

These factors point toward two types of consumer installment credit regulation, based on the same essential protective principles but differing markedly in detail and in the elaborateness of the precautions. As the use of consumer installment credit has penetrated into the larger amounts per transaction, the states have frequently confused the need for less regulation with a justification for no regulation. That omission characterized the period of about fifteen years prior to I940, during which the newer installment credit agencies entered the field. The last eight years, however, have seen legislative recognition of the need for regulation in these areas.

The difficulties of harmonizing, let alone unifying, the diverse institutions, methods, and practices of consumer installment creditors seem obvious. It has been suggested that this is a task for those responsible for

gaged in making weekly and periodical loans, payable in installments on charges varying from I5 per cent per annum to 200 per cent per annum. The total loans of such offices annually exceed $\$ 1, \infty 00, \infty 00$. It is disclosed by the record that in $1929,18,000$ actions were instituted in the court of one justice of the peace of Jefferson county; 8,000 in another during a period of six months; 23,000 in the court of one justice of the peace in I93I; 73,000 actions were commenced, tried, and judgments rendered in the courts of the justices of the peace in $193 \mathrm{r} ; 30$ writs of forcible detainer were issued in one day, and approximately 2,000 garnishments in one month in 1932." Shaw v. Fox, 246 Ky. 342, 55 S.W. 2 d II (1932).

For oppression of small borrowers, their economic weakness, and inequality of bargaining power, see also note 2 supra; Simpson, The Small Loan Problem of the Carolinas 79 (Presbyterian College Press, Clinton, S.C., I94I); Report of the Interim Committee of the House of Representatives, Minn., Small Loan Legislation, p. I6 (r929). 
our Uniform State Laws and our Restatements. The American Law Institute and the National Conference of Commissioners on Uniform State Laws have been working for the past several years on a proposed uniform commercial code containing a division on secured commercial transactions with a subdivision on consumer credit. In a recent article ${ }^{67}$ it is pointed out that this would be embarking on a field of social legislation and that there may be considerable doubt as to the propriety of including such regulation in a statute relating to security concepts. The author refers to this area as a battleground in which it would be necessary to take into consideration not only the business of sales finance but also of personal finance:

This will create problems galore. Just to mention a few, with respect to small loan and industrial bank regulations, what of rates and what of a licensing provision, which in many states is almost a matter of grace on the part of administrative officials, where licenses can be granted only on the ground of public convenience and necessity? In the sales finance field, a full and complete disclosure of price and terms to the buyer and specified redemption rights are certainly unobjectionable from anyone's viewpoint; but here what of delinquency charges, rates, rights to a deficiency, absolute possessory rights on default and refunds? Uniformity of opinion on all of these various aspects of such regulation is completely lacking.

The author has not overstated the confusion or the difficulties inherent in a consumer credit code.

Nevertheless, the task is a challenging one. Certainly the subject is of national importance and the need is increasing. On February I4, I949, the Chairman of the Board of Governors of the Federal Reserve System made a statement before the federal Joint Committee on the Economic Report, a portion of which was a plea by the Board to be given power to regulate consumer credit, presumably in only its broadest economic aspects. Even giving weight to the fact that it was in a bureau's request for additional prerogatives, it is illuminating to compare some of the statements made with the universally disparaging public attitude toward consumer credit during the formative period from I9I0 to I930:

Instalment credit is the volatile and dynamic element in consumer financing. It is subject to wide fluctuations and exerts a pervasive effect on consumer demand and prices. ... Consumer instalment credit, furthermore, is directly associated with the distribution and financing of durable goods. . . . Thus instalment financing is subject to a growth force that is basic and persisting and is becoming a more important element in the economy. .8

${ }^{67}$ Ireton, The Proposed Commercial Code: A New Deal in Chattel Security, 43 Ill. L. Rev. 794, 804 (1949).

${ }^{68}$ Statement on Behalf of the Board of Governors of the Federal Reserve System before the Joint Committee on the Economic Report (Feb. I4, x949), presented by Chairman Thomas B. McCabe (p. 6 of leaflet insert to Fed. Reserve Bull., Feb. 1949). 
If that is true, it seems inevitable that our legislative processes will continue to work toward the imposition of a systematic plan of regulation covering all consumer installment credit agencies in a manner which holds them to uniform standards of conduct consistent with the public interest. Recent progress is in that direction although it has been fumbling and erratic. In due course, after enough parts of the subject matter have been dealt with separately, the basis will exist for the comprehensive scientific treatment which Professor Bogert called for in I944. 